\title{
Correlation between acanthosis nigricans and insulin resistance in obese children in Manado
}

\author{
Arief Gunadi, Vivekenanda Pateda, Adrian Umboh, Kristellina Sangirta Tirtamulia \\ From 7th APPES Biennial Scientific Meeting \\ Nusa Dua, Bali. 14-17 November 2012
}

\section{Background}

Acanthosis Nigricans, which is a skin condition characterized by darkening and thickening of skin caused by papillomatosis and hyperkeratosis has been reported to be linked to insulin resistance and is thought to be a major factors in type 2 diabetes mellitus.

\section{Objective}

To determine whether the presence of acanthosis nigricans in obese children is related with insulin resistance.

\section{Methods}

We performed a cross sectional analytic observational study. One hundred twenty three obese children, ages $10-14$ years with and without acanthosis nigricans got examined for insulin resistance using Homeostasis Model Assessment of Insulin Resistance Index (HOMA-IR). Diagnosis of acanthosis nigricans is confirmed by a dermatologist. This study took place in Wenang district, Manado, North Sulawesi from October 2009 until January 2010.

\section{Results}

Acanthosis nigricans was found positive in 33 children (61.1\%). We found insulin resistance in $84.4 \%$ of obese children with acanthosis nigricans. There was a positive correlation between acanthosis nigricans and obese children with insulin resistance $(\mathrm{r}=0.568, \mathrm{p}<0.001)$.

\section{Conclusion}

Children with acanthosis nigricans are more likely have insulin resistance. Therefore, we need to identify acanthosis nigricans in obese children for the possibility of diabetes mellitus type 2 so early intervention can be done.

Department of Child Health, Faculty of Medicine, Sam Ratulangi University, DR R.D. Kandou General Hospital, Manado, Indonesia
Published: 3 October 2013

doi:10.1186/1687-9856-2013-S1-P95

Cite this article as: Gunadi et al:: Correlation between acanthosis nigricans and insulin resistance in obese children in Manado. International Journal of Pediatric Endocrinology 2013 2013(Suppl 1):P95.
Submit your next manuscript to BioMed Central and take full advantage of:

- Convenient online submission

- Thorough peer review

- No space constraints or color figure charges

- Immediate publication on acceptance

- Inclusion in PubMed, CAS, Scopus and Google Scholar

- Research which is freely available for redistribution 